\title{
A Blueprint for Translational Regenerative Medicine
}

\author{
James P. K. Armstrong, ${ }^{1,2,3}$ Timothy J. Keane, ${ }^{1,2,3}$ Anne C. Roques, ${ }^{2}$ P. Stephen Patrick, ${ }^{4}$ Claire M. Mooney, ${ }^{5}$ \\ Wei-Li Kuan, ${ }^{6}$ Venkat Pisupati, ${ }^{6}$ Richard O. C. Oreffo, ${ }^{7}$ Daniel J. Stuckey, ${ }^{4}$ Fiona M. Watt, ${ }^{5}$ Stuart J. \\ Forbes ${ }^{8}$ Roger A. Barker ${ }^{6} \&$ Molly M. Stevens ${ }^{1,2,3}$
}

1. Department of Materials, Imperial College London, London, SW7 2AZ, UK

2. Department of Bioengineering, Imperial College London, London, SW7 2AZ, UK

3. Institute of Biomedical Engineering, Imperial College London, London, SW7 2AZ, UK

4. Centre for Advanced Biomedical Imaging, University College London, London, WC1E 6DD, UK

5. Centre for Stem Cells and Regenerative Medicine, King's College London, London, SE1 9RT, UK

6. John van Geest Centre for Brain Repair and WT-MRC Cambridge Stem Cell Institute, University of Cambridge, Cambridge, CB2 OPY, UK

7. Centre for Human Development, Stem Cells and Regeneration, University of Southampton, Southampton SO16, 6YD, UK

8. MRC Centre for Regenerative Medicine, University of Edinburgh, Edinburgh, EH16 4UU, UK

\begin{abstract}
The last few decades have produced a large number of proof-of-concept studies in regenerative medicine. However, the route to clinical adoption is fraught with technical and translational obstacles that frequently consign promising academic solutions to the so-called "valley of death." This review is intended to serve as a blueprint for translational regenerative medicine: we suggest principles to help guide cell and material selection, present key in vivo imaging modalities and argue that the host immune response should be considered throughout therapeutic development. Finally, we suggest a pathway to navigate the often complex regulatory and manufacturing landscape of translational regenerative medicine.
\end{abstract}

\section{Key Words}

Regenerative medicine; tissue engineering; cells; biomaterials; translation 


\section{Regenerative Medicine: A Key Curative Strategy for the $21^{\text {st }}$ Century}

The great success of vaccines, antibiotics, statins and other major therapies have reshaped the landscape of preventative and curative medicine. In particular, the aging population demographic has led to the rise of regenerative medicine, which typically employs combinations of cells, biomaterials and biomolecules in order to rejuvenate or replace damaged or diseased tissue (Figure 1). The development of clinically-viable regenerative therapies is challenging and thus, we sought to write guidelines based on our experiences as part of the UK Regenerative Medicine Platform. We outline key criteria for selecting cells and biomaterials, summarize the major clinical options for tissue assessment and provide a roadmap for navigating key immunological, regulatory, manufacturing and translational hurdles. We hope that these guidelines will enable researchers in the field to avoid the common pitfalls of translational regenerative medicine and aid in the design of smart, holistic strategies with improved prospects of clinical adoption.

\section{The Regenerative Potential of Cells}

\section{Cells as Regenerative Agents}

Natural cellular processes can be used as inspiration for regenerative medicine. During embryogenesis and post-natal growth, stem and progenitor cells generate specialized progeny that build and maintain tissues by cellular assembly, extracellular matrix (ECM) secretion and enzymatic remodeling. Normal wound healing is also regulated by coordinated cellular processes: the first responders to injury are platelets and neutrophils, which aggregate at the wound site and release growth factors and chemoattractants that trigger the recruitment of macrophages, lymphocytes, fibroblasts and endothelial cells. These cells remove damaged tissue and populate the wound site with a collagenous granulation tissue that is gradually remodeled into vascularized ECM (1). The processes involved in development and wound healing highlight the regenerative potential of cells. These natural precedents offer insights into how we can repair damaged tissue and provide a rationale for therapies that seek to replace diseased or damaged cells, or modulate the host environment to promote endogenous regeneration. 
The biological complexity underpinning tissue regeneration necessitates a careful selection process guided by both technical and practical considerations. A first criteria is whether cells are sourced from the patient (autologous) or a donor (allogeneic). Allogeneic therapies are attractive if cells can be readily sourced and used "off-the-shelf," however, the risks of immune rejection and iatrogenic infection mean that autologous therapies are often preferred for translation, even if these cells retain some of the defects that originally led to the disease in that individual. A second criteria is whether to use like-for-like cell replacement, such as autologous chondrocyte implantation for the repair of cartilage defects (2), or to employ cells out of context, such as the injection of skeletal myoblasts for cardiac regeneration (3). A third criteria is whether to use committed cell types, already specialized and functional, or stem cells that have the capacity for prolonged or unlimited self-renewal under controlled conditions and the potential to secrete a range of factors and differentiate into a variety of specialized cell types.

Mesenchymal stem cells (MSCs), hematopoietic stem cells (HSCs) and neural stem cells (NSCs) are examples of cells that exhibit multipotency; the capacity to differentiate into a small subset of cell lineages (4). A common alternative are cells that exhibit pluripotency; the ability to differentiate into any cell of the three germ layers (endoderm, mesoderm, ectoderm). Embryonic stem cells (ESCs) are naturally pluripotent but are restricted by their allogenic and ethically-controversial cell source. Meanwhile, induced pluripotent stem cells (iPSCs) can be generated by reprogramming autologous somatic cells, such as fibroblasts (5) or other abundent cell types (6). The controlled in vitro differentiation of iPSCs has enabled the derivation of a wide range of therapeutic cell types that would be otherwise challenging to source. However, a clinical hurdle in using iPSCs and ESCs is the inherent tumorigenicity associated with pluripotency, either through benign teratoma formation of undifferentiated cells or malignant transformation of differentiated progeny (7).

\section{Redefining the Cellular Role}

Induced pluripotency radically redefined our understanding of cell state and offered a striking example of cell plasticity: the concept that cells can readily adopt different phenotypic identities. This viewpoint sparked 
intensive research into reprogramming strategies that converted somatic cells without the need for an iPSC intermediate. One method appeared to show that a brief pulse of Yamanaka factors could create a transient cell state that could be biochemically differentiated to various progeny, however, it is unclear whether this method truly bypasses pluripotency (8). Another approach involves somatic cell reprogramming using lineage-specific transcription factors, which has been used to generate a variety of regenerative cells, such as cardiomyocytes (9), neurons (10), and hepatocytes (11). These "transdifferentiation" strategies are restricted by low yields and the lack of cell rejuvenation, however, they do offer a cheaper and faster route than iPSCs for deriving regenerative cell lines and, to date, appear to mitigate the inherent risk of tumorigenicity associated with pluripotent cells (12).

A major consideration for the translation of pluripotent cells (ESCs and iPSCs) is the emergence of potentially dangerous genetic and epigenetic variants. In vitro culture creates bottlenecks, such as postplating survival, cell-cycle checkpoints and post-mitotic survival of daughter cells, which favor cells with certain acquired mutations, such as copy-number variants overexpressing $B C L 2 L 1$ (13). This genetic variance can result in aberrant lineage specification, growth factor and niche independence, and increased frequency of tumor-initiating cells (14). Moreover, loss of genomic imprinting and erosion of chromosome inactivation can arise during pluripotent stem cell culture $(15,16)$. Such culture-induced perturbations represent a latent safety risk for ESC and iPSC therapies. Accordingly, there has been a focus on screening clonal cell lines to understand and catalog the functional significance and risk associated with such changes (e.g., tumorigenesis), in order to aid the development of culture conditions that could slow the emergence of variant cells (17).

A number of studies have indicated that screening can also be used to identify cell subpopulations with enhanced regenerative potency. For instance, Dickinson et al. used fluorescence-activated cell sorting to isolate a subset of highly chondrogenic human MSCs, which were used to provide quantitatively improved outcomes in the treatment of articular cartilage defects (18). In another example, Kirkeby et al. performed a large-scale analysis into the global gene expression profile of human ESC-derived dopaminergic neuroprogenitors on the day of intrastriatal transplantation in a rat model of Parkinson's disease. Predictive 
markers expressed by midbrain dopaminergic neurons close to the midbrain-hindbrain boundary region correlated with a successful graft outcome, while markers expressed in the diencephalic domain were negatively associated (19). Such studies can aid in the identification of optimal culture protocols, improve clinical reliability through reduction of biological variability, help to define acceptable levels of genetic variance in cell-based products, and offer a quality control, defined release assay for cells that need to differentiate in vivo for efficacy.

\section{Orchestrating Regeneration}

\section{Interactive and Dynamic Biomaterials}

Stem cells reside in distinct anatomical microenvironments, known as niches, in which the surrounding ECM, soluble factors, immobilized biochemicals and local niche cells present a dynamic array of signals that instruct the resident cells to remain quiescent, undergo self-renewal, differentiate, or die (20). Regenerative biomaterials are typically designed to play a similar functional role, interacting with interfaced cells and the host environment in order to elicit targeted biological responses. This can be guided by cell-material interactions that can be nonspecific (e.g., electrostatic binding, lipid anchoring) or specific (e.g., ligand binding to integrins or organized proteoglycan domains) $(21,22)$. The cellular interaction of biomaterials can also be tuned by modulating protein adsorption. For example, hydrophobic materials can be used to adsorb albumin, an abundant serum protein that blocks cell adhesion, while slightly hydrophilic substrates can be used to adsorb fibronectin, a cell-binding protein (22).

Cell-material interactions are also guided by interfacial geometry. It is widely accepted that biomaterials that offer a 3D network, such as microfibrous scaffolds or nanofibrous hydrogels, can provide a more biomimetic cell culture environment than 2D substrates (23). Moreover, topographical cues provide an effective means to regulate adhesion, migration, differentiation, epigenetic state or cell reprogramming (24). Many of these biological responses are achieved by mechanosensing, in which the interfaced cells respond to extracellular forces through deformation, mechanosensitive ion channel activation, or integrin binding and signal transduction (25). For instance, cells originating from softer tissues (e.g., neural) can show improved 
biological response when cultured on low-stiffness biomaterials (26). These observations have popularized the use of biomaterials with tissue-matched mechanical properties, however, this approach often overlooks the complex changes in tissue mechanics that occur during physiological development (27). In this regard, biomaterials that provide spatial and temporal differences in substrate mechanics can provide a more natural biological response $(28,29)$.

Biomaterials that can undergo dynamic phase changes are also widely used in regenerative medicine; consider the different transitions exploited in bioprinting (30), micromolding (31) and biomaterial injection (32). Meanwhile, controlled degradation can be used to enhance the maturation of engineered tissues or release cargo from biomaterial vectors. This can be achieved by using synthetic biomaterials that slowly hydrolyze into non-toxic byproducts, while additional control can be leveraged by using biomaterials susceptible to enzymatically-catalyzed degradation (33). For example, cartilage engineered using chondrocyte-laden agarose can be cultured with agarase to degrade the hydrogel and provide the growing tissue with additional space for nutrient diffusion and matrix assembly (34). Another example is the use of materials crosslinked with peptides subsequently cleaved by specific catabolic enzymes. This approach can be used in regenerative medicine to create drug delivery systems that are responsive to particular in vivo environments (e.g., inflammation), or biomaterial systems with programmed degradation profiles for in vitro tissue engineering (33).

\section{Immunology and Regenerative Medicine}

\section{The Host Immune Response}

Vertebrates have evolved an innate and an adaptive immune system that aims to eliminate invading pathogens, toxic substances and allergens without causing harm to the host. Innate immunity is an ancient defense mechanism found in all multicellular organisms and involves a non-specific inflammatory response after recognition of a foreign substance (35). Many pathogens exhibit conserved pathogen-associated molecular patterns that can be recognized by immune cells bearing pathogen recognition receptors (36). Upon detection of a foreign body, the innate immune system initiates phagocytosis, apoptosis, opsonization 
and the activation of pro-inflammatory signaling pathways $(35,36)$. Adaptive immunity is a highly-specific antigen response that provides long-term immunological memory via either cell-mediated or antibodymediated (humoral) immunity (37). Adaptive immunity involves the activation of T cells, B cells and natural killer cells, while innate immunity is regulated by polymorphonuclear cells and mononuclear phagocytes, such as dendritic cells, monocytes and macrophages.

The immune system is implicated in many diseases targeted by regenerative medicine, moreover, the recognition and elimination of foreign entities by the host immune system presents several issues for therapies that involve the administration of exogenous cells, tissues or biomaterials. For instance, nonautologous cells can activate the host adaptive immune system through either direct or indirect allorecognition, leading to cell-mediated or antibody-mediated cytotoxicity (Figure 2A) (38). The severity of the initial allorecognition response scales with the degree of antigen mismatch between the donor and recipient cells. Major histocompatibility complex (MHC) matching between the donor and recipient is used clinically to mitigate allorecognition, however, even well-matched donors are capable of provoking unwanted immune responses (39). Critically, therapies based on autologous hiPSCs can also elicit an immune response, potentially due to the use of relatively immature cells or the effect of cell reprogramming, xenogeneic supplements and/or non-physiological culture conditions (40).

An immune response can also be elicited by the implantation of acellular or cellularized biomaterials (41). Many regenerative therapies require the implanted biomaterial to integrate with the surrounding environment to provide long-term restoration of biological function. In reality, implanted biomaterials often provoke a host immune response, known as a foreign-body reaction, that can hinder integration and functional performance (42). Initially, a blood-biomaterial interaction leads to the formation of a protein film and provisional matrix at the biomaterial surface, which is then followed by acute and chronic inflammation. At this stage, macrophages fuse to produce foreign body giant cells, granulation tissue is deposited and then a fibrotic capsule is formed around the biomaterial (Figure 2B). It should be noted that the foreign-body reaction is a chronic pathology and thus more of an issue for long-term, nondegradable grafts rather than transient or biodegradable materials. 


\section{Evading or Harnessing the Immune System}

The nature and magnitude of the host immune response to a regenerative therapy is dependent on several factors, such as the properties of the cell or biomaterial, the implant location and the environmental conditions. For instance, while many cell types commonly provoke a host immune response, other cell types are thought to provide a level of immunosuppression (43). Meanwhile, the immunogenicity of a biomaterial can be affected by a number of properties, such as porosity, surface chemistry, size and shape (44). Given these complexities, it is evident that a holistic understanding can allow the design of regenerative therapies that are compatible with the host immune system. Classically, this has involved the design of immune evasive therapies that attempt to circumvent the immune response in order to allow the implanted therapeutic to perform its intended role with minimal interference from the host.

For example, the initial allorecognition response can be mitigated by using biomaterials with certain properties; a well-known example is the harnessing of hydrophilic polymer coatings to attenuate recognition, opsonization and clearance (45). Biomaterial cell encapsulation can also be used to provide a physical barrier that aims to limit direct cell-cell interactions with the host immune system (46). An elegant, biological approach is the use of cells derived from iPSCs isolated from immune-privileged sites, which appear to retain an epigenetic memory of immune evasion (47). Moreover, recent work has shown that inactivation of MHC classes I and II, combined with overexpression of CD47, produces hypoimmunogenic iPSCs that can avoid rejection in allogeneic hosts (Figure 2C) (48). Other approaches include the inhibition of T-cell activity using pharmacological or cell-based immunosuppression, the genetic modification of cells to express tolerogenic antigens or remove immunogenic epitopes, or the immunization of the host to specific cellsurface markers (38).

These examples highlight the classic view that the immune response should be suppressed or evaded during therapy. However, the immune system can also be a fundamental orchestrator of tissue repair, with many regenerative processes regulated by macrophages, a heterogeneous cell population with a dynamic phenotype that resides between a pro-inflammatory (M1) state and an anti-inflammatory (M2) state. This 
cellular plasticity is driven by environmental signals and is central to both the formation and degradation of scar matrix (49). These features have prompted the design of immune-interactive biomaterials with the aim of polarizing macrophages towards the M2 phenotype (Figure 2D) (50). Materials can also be used to deliver pro-regenerative factors: for instance, gold nanoparticles decorated with interleukin-4 have been used to direct M2 polarization of macrophages and improve the function of injured muscle (51). These, and other findings, offer a fresh perspective on how immunomodulation can be an intrinsic component of regenerative medicine.

\section{Measuring \& Visualizing Tissue Regeneration}

\section{In Vivo Tissue Profiling}

In vivo imaging has revolutionized disease diagnosis and monitoring by offering invaluable tools that can assess tissue status in a minimally-invasively, quantitative, and spatiotemporal manner. Magnetic resonance imaging (MRI), computed tomography (CT) and ultrasound (US) are the clinical state-of-the-art for visualizing structural, functional, molecular and mechanical tissue properties, and can be used in preclinical/clinical trials of regenerative therapies. For instance, multimodal MRI has been used to measure the impact of intramyocardial stem cell injections on scar size, tissue perfusion and circumferential strain in patients with heart disease (52). Meanwhile, emerging modalities present new opportunities for in vivo interrogation of regenerative mechanisms. For example, hyperpolarized ${ }^{13} \mathrm{C}$ MRI can increase sensitivity by 40,000-fold compared to standard MRI (53). This has enabled the metabolism of injected labelled metabolites to be visualized clinically (54), offering the possibility for linking new metabolic diagnostic biomarkers to degeneration and repair.

Optical coherence tomography and confocal microscopy offer a clinical imaging route for assessing retinal or corneal regeneration $(55,56)$. However, visible light is highly absorbed and scattered by most biological tissues, compromising the spatial resolution of light-based methods for deep-tissue imaging. However, by combining optical excitation with US detection, photoacoustic imaging (PAI) enables high-resolution, deeptissue imaging with clear potential for clinical translation (57). This exploits the photoacoustic effect, in 
which molecular absorption of incident photons triggers a thermally-induced pressure jump that releases US waves. PAI has been used to evaluate vascular reperfusion, blood oxygenation and whole-brain neural activity in small animal disease models $(58,59)$. An exciting development for resolving dynamic tissue processes is four-dimensional functional US imaging, which can provide volumetric recordings at high spatiotemporal resolution. This has been used to evaluate neural connectivity and map whole-brain wave propagation (60), thus providing new opportunities for measuring the efficacy of neuro-regenerative therapies.

\section{In Vivo Monitoring}

Resolving the fate of an administered therapeutic, including bio-distribution, engraftment, migration, embolism and clearance, is essential for understanding the mechanism, technical constraints and safety profile of a regenerative strategy. In vivo imaging can be adapted to visualize implanted therapeutics, such as the CT-based monitoring of high-contrast biomaterials (e.g., ceramics) (61) or repair processes (e.g., bone ingrowth into an implanted scaffold) (62). However, therapies involving smaller entities (e.g., cells, particles, extracellular vesicles, biomolecules) generally require a more sensitive imaging modality. One option is nuclear imaging of therapeutics labeled with radionuclides that either release $\gamma$-rays for single-photon emission computed tomography (SPECT), or positrons that annihilate with electrons in the host tissue to produce $\gamma$-rays for positron-emission tomography (PET) (63). In each case, it is important to use radiolabeling methods that provide high contrast across the imaging period, without the radionuclide dissociating, causing significant toxicity or altering the performance of the therapeutic entity.

Radiolabeling small molecules and proteins typically involves covalent or electrostatic binding (64), while non-specific metabolic radiotracers can be taken up by cells, which has been used to track the fate of administered peripheral-blood CD34+ cells (65) and the engraftment of islet cells (66). Targeted approaches can provide process-specific readouts, for instance, ${ }^{18} \mathrm{~F}$-dihydroxyphenylalanine can traverse the blood-brain barrier and be taken up by presynaptic terminals of dopaminergic projections, providing information regarding the survival and maturation of transplanted dopaminergic neurons (67). Similarly, a radiolabeled 
dopamine D2 receptor antagonist, ${ }^{11} \mathrm{C}$-raclopride, can be used to visualize synaptic dopamine release from stimulated, transplanted neurons (68). Alternatively, the stable integration of reporter genes into the genome (e.g., using lentiviral transfection) provides the opportunity to track cells in the body over long periods of time. For instance, the expression of an enzyme (HSV-TK1) that selectively traps ${ }^{18}$ F-fluoro-3[hydroxymethyl]butyl)guanine can be used to provide cellular contrast with PET (69). The recent introduction of high-sensitivity, whole-body PET scanners have been used clinically with reduced imaging time and radionuclide dose, offering greater ease for monitoring regenerative therapeutics in patients compared to current scanner designs (70).

\section{Delivering Patient Benefit: Clinical Translation}

\section{A Blueprint for Translational Medicine}

The last two years has seen the publication of results from several promising clinical trials (Table 1). In phase I clinical trials, Moroni et al. established the safety profile of peripheral infusions of autologous monocyte-derived macrophages in nine patients with compensated liver cirrhosis (71). Da Cruz et al. reported improvements in visual acuity and no significant safety issues following the implantation of synthetic membranes, seeded with human ESC-derived retinal pigment epithelium, in two patients with agerelated macular degeneration (72). Curtis et al. reported no adverse effects, and early indications of therapeutic efficacy, after local delivery of human NSCs in four individuals with spinal cord injury (73). Meanwhile, clinical investigation of iPSC-derived retinal pigment epithelium as a treatment for macular degeneration (74) has been followed by iPSC-based clinical trials for a range of indications, including corneal disease (75), spinal cord injury (76), and Parkinson's disease (77).

The success of these trials, and other translational studies, will be determined by a variety of factors. Ultimately, the most important aspect of translation is the demonstration of robust patient safety and efficacy through preclinical and clinical trials. However, even safe and efficacious therapies can be thwarted by other translational pitfalls; products may be cost ineffective and not competitive against current therapies, challenging to manufacture at scale, or restricted by regulatory requirements in a particular sector or market. 
Here, we provide a blueprint for translation of academic ideas into clinical regenerative medicine, focusing on key stages and milestones that researchers should address in the early stages of translation in order to build a strong basis for product development and the compilation of a technical file for regulatory submission (Figure 3). To provide context, we also discuss later translational stages, although by this stage, activity will typically have transferred from academic to an industrial setting (licensing or start up).

\section{Commercial Considerations}

Translating a regenerative therapy is expensive: in the United States of America (USA), it can cost US\$150250 million to take a cell-based product through phase III clinical trials (78). Although there are established business models for translational regenerative medicine (79), the associated costs and risks dictate that capital investment is almost always required. However, many venture capitalists are justifiably wary after the high-profile failures of the 1990s, in which several tissue engineering products were unprofitable despite being shown to be safe and efficacious (80). Steps should be taken to ensure freedom to operate (FTO) in the desired area and to protect intellectual property (IP). Since these factors can greatly influence the technical components of a proposed strategy, such as cell line selection, researchers should engage technology transfer teams early in the translational process to review FTO and establish IP strategy before publishing any details of the invention.

It is also important to establish whether the translational product will meet an "unmet need." Clinicians must be consulted and competitor reviews performed to ascertain the advantages of the proposed therapy over the current standards of care and competing systems. This assessment should be carried out at the early stages of translation and must cover the treatment pathway as well as clinical outcomes and product costs. Will the proposed product be available "off-the-shelf'? Would the proposed mode of delivery reduce costs of invasive surgery and associated complications? Could the proposed therapy be used to treat a broader spectrum of patients? These practical considerations form the basis of the cost-effectiveness of a proposed solution and will greatly influence the design of the final product. This is important as the decision makers 
for product adoption assess products on economic benefits in their healthcare setting, rather than on clinical promise.

\section{Regulatory Considerations}

In the USA, products are regulated as human cells, tissues, and cellular and tissue-based products (HCT/Ps), devices, biologics or drugs based, in part, on their "primary intended purposes" (78). The European Union (EU) has a similar classification of advanced therapy medicinal products (ATMP), medical devices or medicinal substances based on the "principal intended action" (81). These classifications determine the applicable regulations and are relatively easily applied to single-part therapies, such as acellular scaffolds. For multi-component systems, such as cell-seeded scaffolds, the legal manufacturer must comply with applicable regulatory requirements for all components. While the regulations are necessarily stringent, schemes such as the Breakthrough Therapy designation (USA), the Regenerative Medicine Advanced Therapy designation (USA), the Sakigake designation (Japan), and the PRIME initiative (EU) are available to support patient access to innovative medicines with high public health potential (82). Regulatory strategies should ideally be devised in consultation with a regulatory expert, once the unmet need and intended use have been defined.

\section{Preclinical and Clinical Studies}

Before a product can be authorized for market release, the legal manufacturer must demonstrate safety and efficacy for its intended use, in the intended population, for the intended purpose. In the early stages, researchers should clearly define these clinical parameters (intended use, population, purpose), how the proposed product achieves a therapeutic effect, and the expected benefits over available alternatives. These claims must, ultimately, be validated by clinical data using endpoints that can quantifiably measure whether the patient undergoing treatment lives longer and/or better than if they received the gold standard therapy or no treatment at all. Real clinical endpoints include higher overall survival, reduced patient symptoms, or improved quality of life (83). Surrogate endpoints, such as disease-free survival and progression-free 
survival, can also provide useful indication of therapeutic efficacy, however, care should be taken as these factors may not necessarily correlate with real clinical endpoints (83).

Clinical studies should be designed in collaboration with clinicians and statisticians, and aided by a systematic review of relevant clinical data. Ideally, preclinical tests are performed using well-validated, highfidelity animal models that in some way mimic the clinical problem. However, accurate modelling can be restricted by differences in physiology, anatomical size, and disease characteristics between animal models and human patients. In addition, preclinical testing with human cells requires immunocompromised animals, which can cause problems when studying long-term effects (>6 months) (84). For clinical testing (i.e., in humans), proposed therapies must progress through a carefully staged process. Initial studies are performed on a small number of participants to test for tolerability and feasibility (phase I), then larger groups are used to test for any signal of therapeutic efficacy (phase II), which is then formally compared to the current standard of care (phase III). Further clinical studies are performed after approval, in order to track long-term benefits and side effects (phase IV).

\section{Manufacturing Considerations}

Successful translation requires manufacturing processes that can be performed reliably and at scale, while remaining financially viable. Unfortunately, the manual handling protocols commonly used in academia can present high technical variability, the risk of contamination, a lack of precision or power, and low throughput production. Moreover, manually-operated systems require expertise knowledge and training. Given these limitations, it is important that automated and mechanized processes are employed, where possible, during product manufacture. Automation uses machines to replicate manual processes, which can greatly reduce technical variance, production costs and the risk of contamination. Automated systems can also benefit from mechanization, in which machines outperform humans in precision, power or throughput (85). Reliability can be improved through other means: by employing strict standard operating procedures, chemicallydefined and batch-tested media of good manufacturing practice (GMP) standard, closed cell systems and 
batch segregation to limit microbial or chemical contamination, and culture protocols known to reduce genetic or epigenetic variability (86).

Harmonized standards are available to support manufacturers in establishing quality management systems (QMS) that can be implemented throughout product development and production. In particular, this framework of quality assurance practices can aid in documenting the design history, product requirements, applicable standards and state-of-the-art test methods, and in performing initial risk assessments, maintaining traceability, characterizing products and monitoring manufacturing processes. For example, it is recommended that cell and tissue culture is performed using bioreactors with integrated sensors that continuously record the media $\mathrm{pH}$, glucose concentration and dissolved oxygen levels (87). These online monitoring systems, and other analytical methods, should be used to generate critical-to-quality (CTQ) attributes. These quantitative metrics are used for product quality control to assess whether changes in critical process parameters (CPP) produce statistically significant differences in safety or efficacy. Equivalence testing should be performed for all process changes, including alterations in protocol, materials, equipment or manufacturing location (88).

One process change that should not be underestimated during early development is scaling: therapies can require hundreds of millions of cells per dose, and manufacturers often need to navigate hurdles of largescale cell expansion (senescence, dedifferentiation, slow proliferation, infrastructure) (89, 90). Scalable cell expansion can be facilitated by automated and mechanized processes, closed cell systems and intermediate cryopreservation stages $(89,90)$. Production rate can then be raised either by scale-out, which involves an increase in the number of units (e.g., bioreactors) with maintained output per unit, or by scale-up, whereby the output per unit is increased. Scale-out is a more predictable process change with additional flexibility over production rate and reduced operating risk, however, scale-up may be more appropriate for allogeneic therapies or highly mechanized manufacture $(90,91)$. To avoid unnecessary operational costs, manufacturing processes should be designed to be scalable but only scaled in line with clinical trials size or market demand (91). 


\section{Risk Management}

Regulations require risk assessments for the whole product, each individual part and any interactions that may occur between components. For example, an engineered graft should be considered in terms of the whole tissue, its constituent cells, materials and biomolecules, as well as any interactive processes (e.g., adhesion, signaling). Technical risks include malignant transformation, component toxicity, disease transmission, immune rejection, and the increased risk of thromboembolic disease, while extrinsic risks can arise during procurement, delivery, handling, storage, surgery, or immunosuppression (92). Given the variety of different factors, it is important to assemble a risk assessment team during the early stages of translation, and include technical, clinical, regulatory and manufacturing expertise to effectively identify, score, and preemptively mitigate potential risks by design. This can be supported by performing an early review of scientific literature, including failure reports and national registry data for similar therapies. An effective risk management strategy, implemented throughout the course of a project, can help avert setbacks that can consign an idea to the translational "valley of death."

\section{Future Perspectives}

These are truly exciting times for regenerative medicine, at the confluence of cutting-edge biological manipulation (e.g., iPSCs, CRISPR/Cas9, optogenetics), powerful in vitro models (e.g., organoids, organ-ona-chip, 3D bioprinting, machine learning) and advanced characterisation tools (e.g., spatially-resolved omics, super-resolution microscopy, machine learning) (93). We must strive to use such innovative methods to improve our understanding of disease targets, better resolve the fate of implanted therapeutics and unravel the mechanisms underpinning tissue regeneration. These outcomes should provide solid scientific foundations for the major challenge of the field: to assemble efficacious, reproducible and scalable therapies that offer programmed tissue regeneration within a robust regulatory and manufacturing pipeline. We hope that the biological, material, immunological, imaging and translational aspects that we have highlighted in this review can serve as a blueprint for those seeking to turn academic ideas into clinical regenerative medicine products providing real patient benefit. 


\section{Tables}

Table 1. Selection of published clinical trials of regenerative therapies since 2018

\begin{tabular}{|c|c|c|c|}
\hline Indication & Trial Details & Regenerative Therapy & Reference \\
\hline $\begin{array}{l}\text { Macular } \\
\text { degeneration }\end{array}$ & $\begin{array}{l}\text { - Phase I } \\
\text { - } 2 \text { patients }\end{array}$ & $\begin{array}{l}\text { Human iPSC derived retinal pigment } \\
\text { epithelium delivered on a PET membrane. }\end{array}$ & $\begin{array}{l}\text { L. Da Cruz et al. Nat. } \\
\text { Biotechnol. } 2018 \text { (72) }\end{array}$ \\
\hline $\begin{array}{l}\text { Thoracic spinal } \\
\text { cord injury }\end{array}$ & $\begin{array}{l}\text { - Phase I } \\
\text { - } 4 \text { patients }\end{array}$ & $\begin{array}{l}\text { Human NSCs (NSI-566) injected locally } \\
\text { using a stereotactic floating cannula. }\end{array}$ & $\begin{array}{l}\text { E. Curtis et al. Cell Stem } \\
\text { Cell } \mathbf{2 0 1 8} \text { (73) }\end{array}$ \\
\hline $\begin{array}{l}\text { Ischemic } \\
\text { stroke }\end{array}$ & $\begin{array}{l}\text { - Phase I } \\
\text { - } 9 \text { patients }\end{array}$ & $\begin{array}{l}\text { Intra-carotid artery transfusion of } \\
\text { autologous CD } 34^{+} \text {cells in the infarct area. }\end{array}$ & $\begin{array}{l}\text { P.-H. Sung et al. Am. J. } \\
\text { Transl. Res. } 2018 \text { (94) }\end{array}$ \\
\hline $\begin{array}{l}\text { Rheumatoid } \\
\text { arthritis }\end{array}$ & $\begin{array}{l}\text { - Phase I/II } \\
\text { - } 15 \text { patients }\end{array}$ & $\begin{array}{l}\text { Intra-articular injection of cultured, } \\
\text { autologous mesenchymal stem cells. }\end{array}$ & $\begin{array}{l}\text { S. Shadmanfar et al. } \\
\text { Cytotherapy } 2018 \text { (95) }\end{array}$ \\
\hline $\begin{array}{l}\text { Compensated } \\
\text { liver cirrhosis }\end{array}$ & $\begin{array}{l}\text { - Phase I } \\
\text { - } 9 \text { patients }\end{array}$ & $\begin{array}{l}\text { Peripheral infusion of matured autologous } \\
\text { monocyte-derived macrophages. }\end{array}$ & $\begin{array}{l}\text { F. Moroni et al. Nat. } \\
\text { Med. } 2019 \text { (71) }\end{array}$ \\
\hline $\begin{array}{l}\text { Knee } \\
\text { osteoarthritis }\end{array}$ & $\begin{array}{l}\text { - Phase } 2 \\
\text { - } 26 \text { patients }\end{array}$ & $\begin{array}{l}\text { Intra-articular injection of cultured, } \\
\text { autologous mesenchymal stem cells. }\end{array}$ & $\begin{array}{l}\text { L. Lu et al. Stem Cell } \\
\text { Res. Ther. } 2019 \text { (96) }\end{array}$ \\
\hline $\begin{array}{l}\text { Compensated } \\
\text { liver cirrhosis }\end{array}$ & $\begin{array}{l}\text { - Phase } 2 \\
\text { - } 81 \text { patients }\end{array}$ & $\begin{array}{l}\text { Subcutaneous delivery of granulocyte } \\
\text { colony-stimulating factor and intravenous } \\
\text { infusion of CD133 }{ }^{+} \text {HSCs. }\end{array}$ & $\begin{array}{l}\text { P. N. Newsome et al. } \\
\text { Lancet Gastroenterol. } \\
\text { Hepatol. } 2018 \text { (97) }\end{array}$ \\
\hline
\end{tabular}




\section{Figures}

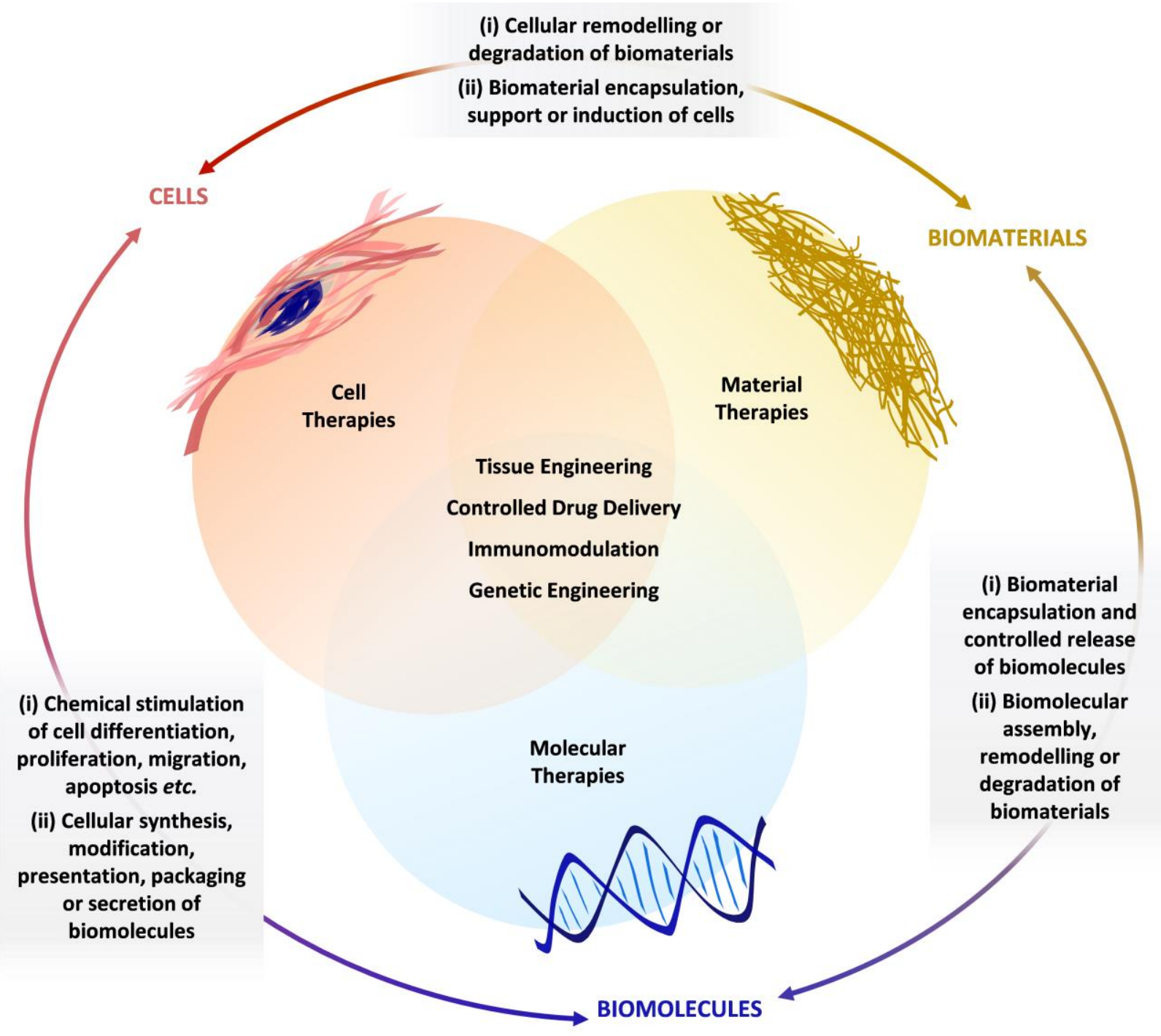

Figure 1 


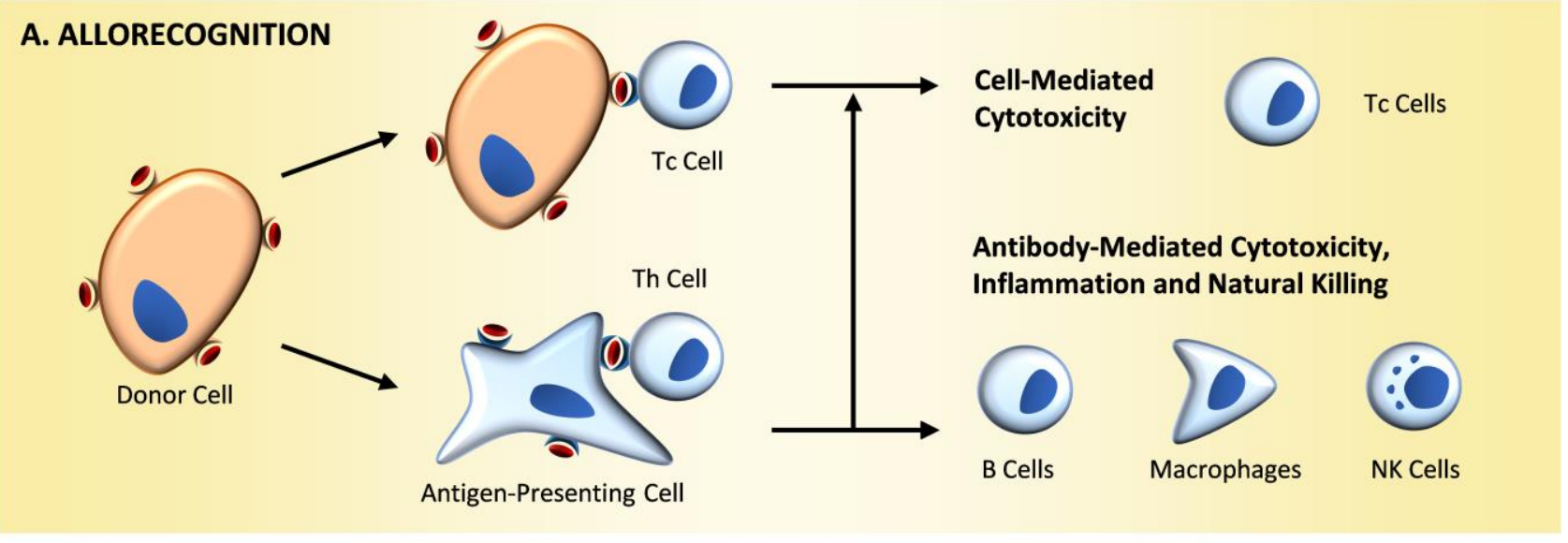

\section{B. FOREIGN BODY REACTION}

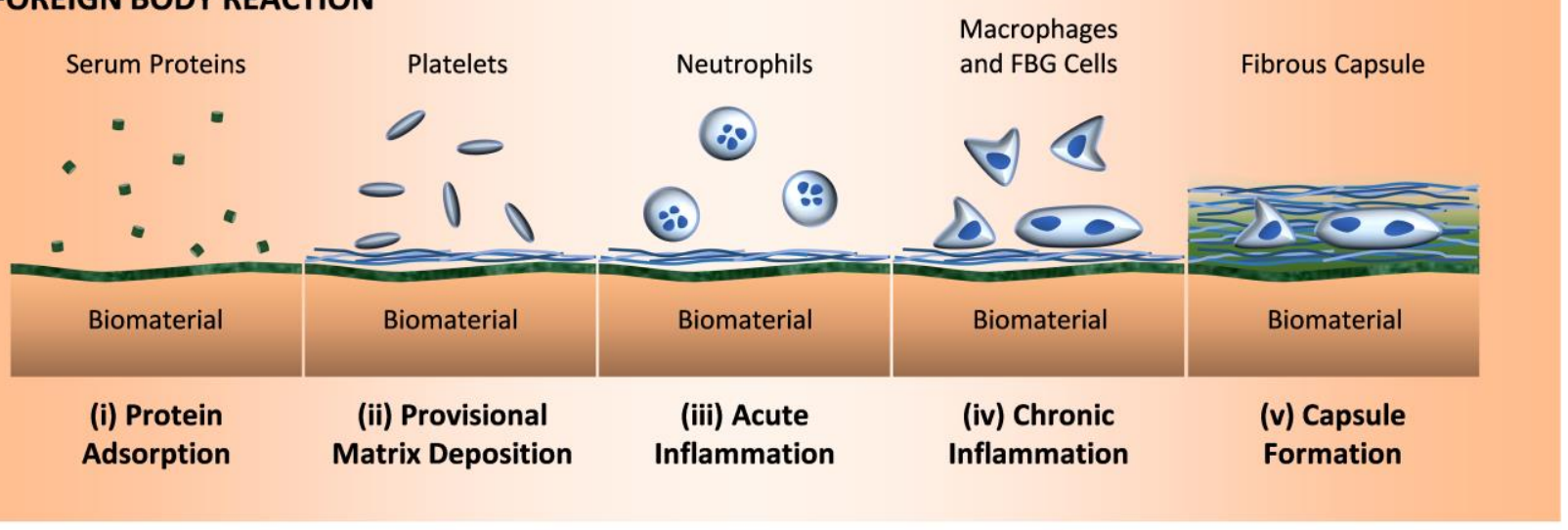

\section{IMMUNE EVASION}

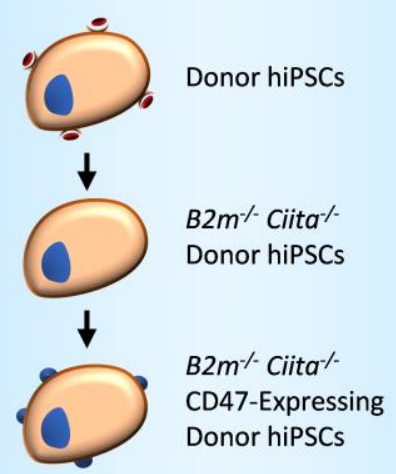

\section{IMMUNE MODULATION}

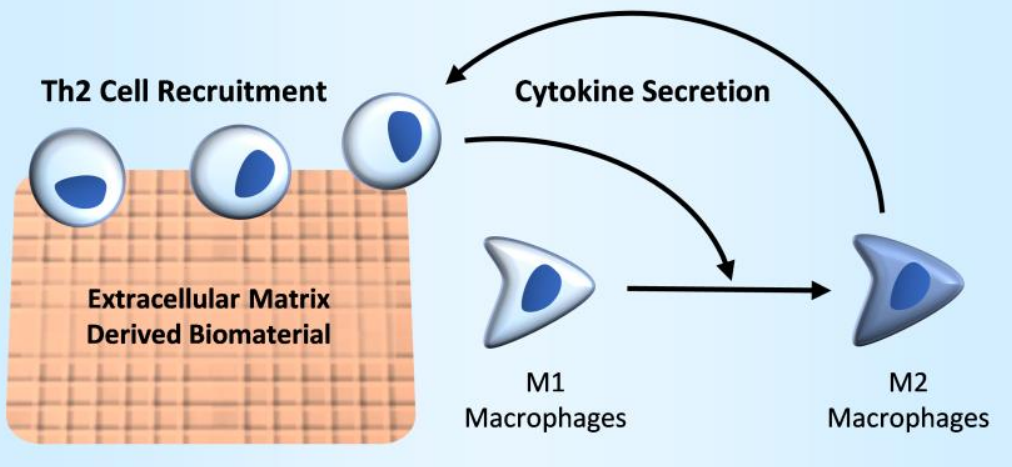

Figure 2 


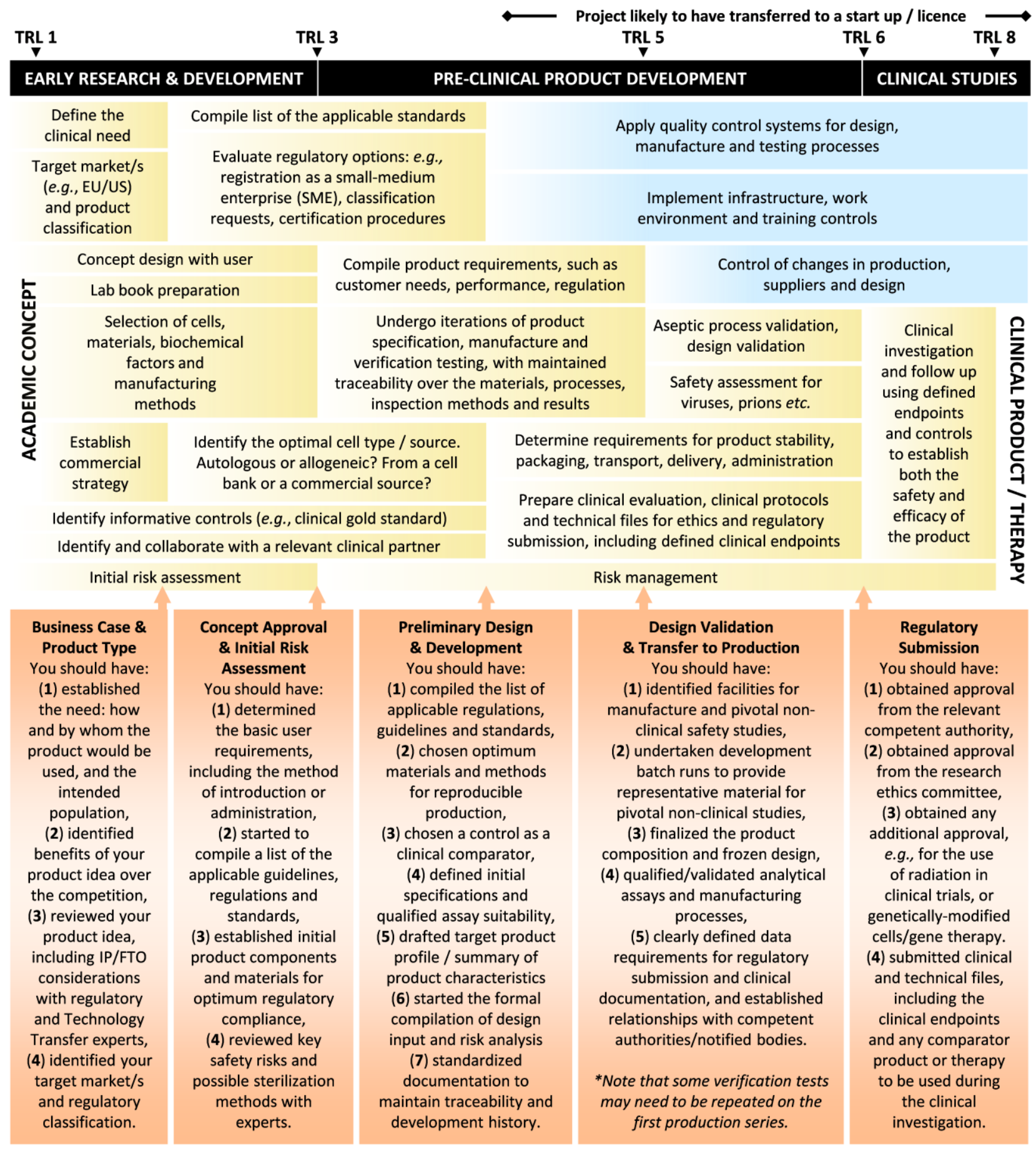

Figure 3 


\section{Figure Legends}

Figure 1. Overview of some common strategies, components and interactions used in regenerative medicine. Cells, biomaterials and biomolecules exhibit a number of interdependent interactions that can be exploited for various regenerative medicine strategies, including tissue engineering, drug delivery, immunomodulation and genetic engineering.

Figure 2. The host immune response and regenerative medicine. (A) Direct allorecognition occurs by cytotoxic T cells (Tc cells) recognizing and eliminating allogeneic donor cells, while indirect allorecognition occurs by helper $\mathrm{T}$ cells (Th cells) recognizing donor antigens taken up and displayed by host antigenpresenting cells. (B) Implanted biomaterials can provoke a foreign body reaction resulting in the formation of a fibrous capsule containing both macrophages and foreign body giant (FBG) cells. (C) An example of immune evasion, in which transgene expression and CRISPR/Cas9 are used to generate hypoimmunogenic hiPSCs with upregulated CD47 but neither class of MHC $\left(B 2 \mathrm{~m}^{-/}\right.$and $\left.\mathrm{Ciita}^{-/}\right)$. (D) An example of immune modulation, in which ECM-derived biomaterials recruit T helper 2 cells (Th2 cells), which secrete cytokines that can polarize macrophages to an M2-like phenotype. In turn, these alternatively-activated macrophages secrete cytokines that sustain Th2 cell activation.

Figure 3. Bench-to-bedside translation of regenerative medicine products. Translating an academic concept into a clinical product can be divided into three key stages: early research and development, pre-clinical product development and clinical studies. This schematic predominantly focuses on the technical aspects that should be considered by scientists at early technology readiness level (TRL), with higher TRL items included for context. Highlighted are the key tasks (yellow boxes), systematic quality control to fulfill all applicable requirements (blue boxes) and critical checkpoints that should be met throughout product translation (orange boxes), with each stage guided by experts in the field. The timeline of this schematic should not be considered an absolute scale, indeed, the relative time and work required at the different stages will vary considerably depending on the product or therapy that is being translated. It should also be noted 
that in the EU, good manufacturing practice (GMP) is applicable for medicines and ATMPs but not for medical devices.

\section{Acknowledgements}

J.P.K.A. acknowledges support from an Arthritis Research U.K. Foundation Fellowship (21138) and the Medical Research Council (MRC) (MR/S00551X/1). T.J.K. acknowledges the European Union's Horizon 2020 research and innovation programme under the Marie Skłodowska-Curie Individual European Fellowship (Grant Agreement No. 746980). A.C.R. acknowledges support from the Wellcome Trust Institutional Translational Partnership Award (208858/Z/17/Z). P.S.P. acknowledges funding from the UK Regenerative Medicine Platform (MR/K026739/1), the MRC (MR/R026416/1), and the EPSRC (EP/R511638/1). C.M.M. was supported by the MRC-funded UK Regenerative Medicine Platform Immunomodulation Hub award (MR/L022699/1). W.L.K. is supported by the MRC/UKRI Innovate Fellowship (MR/S005528/1). V.P. acknowledges funding from the UK Regenerative Medicine Platform (MR/R015724/1). R.O.C.O acknowledges support from the UK Regenerative Medicine Platform "Acellular / Smart Materials - 3D Architecture" (MR/R015651/1), the Rosetrees Trust, Wessex Medical Research and Biotechnology and Biological Sciences Research Council (BBSRC) (BB/P017711/1). D.J.S. acknowledges support from a British Heart Foundation (BHF) Intermediate Basic Science Research Fellowship (FS/15/33/31608), the BHF Centre for Regenerative Medicine (RM/17/1/33377), and an MRC Project Grant (MR/R026416/1). F.M.W. acknowledges support from the UK Regenerative Medicine Platform (MR/LO22699/1, MR/R015635/1, MR/K026666/1). S.J.F. acknowledges support from the UK Regenerative Medicine Platform Engineered Cell Environment Hub and the MRC. R.A.B. acknowledges MRC-WT funding of the Cambridge Stem Cell Institute and MRC funding of the UK Regenerative Medicine Platform Pluripotent Stem and Engineered Cell hub (MR/R015724/1) along with funding from the Rosetrees Trust (A1519 M654) and Cure Parkinson's Trust. R.A.B. is also supported by NIHR funding of Biomedical Research Centre Cambridge (146281). R.A.B. is an NIHR Senior Investigator (NF-SI-0616-10011) and a 
P.I. in the MRC/WT Stem Cell Institute (203151/Z/16/Z). M.M.S. acknowledges support from the grant from the UK Regenerative Medicine Platform "Acellular / Smart Materials - 3D Architecture" (MR/R015651/1), the European Research Council (ERC) Seventh Framework Programme Consolidator grant "Naturale CG" (616417), the Rosetrees Trust and the Wellcome Trust Senior Investigator Award (098411/Z/12/Z). The authors would also like to thank David Pan (MRC) for his input into this manuscript during the course of Phases 1 and 2 of the UK Regenerative Medicine Platform.

\section{References}

1. G. C. Gurtner, S. Werner, Y. Barrandon, M. T. Longaker, Wound repair and regeneration, Nature 453, 314-321 (2008).

2. M. Brittberg, A. Lindahl, A. Nilsson, C. Ohlsson, O. Isaksson, L. Peterson, Treatment of deep cartilage defects in the knee with autologous chondrocyte transplantation, N. Engl. J. Med. 331, 889-895 (1994).

3. P. Menasché, A. A. Hagège, M. Scorsin, B. Pouzet, M. Desnos, D. Duboc, K. Schwartz, J.-T. Vilquin, J.P. Marolleau, Myoblast transplantation for heart failure, Lancet 357, 279-280 (2001).

4. M. R. Alison, R. Poulsom, S. Forbes, N. A. Wright, An introduction to stem cells, J. Pathol. 197, 419-423 (2002).

5. K. Takahashi, S. Yamanaka, Induction of pluripotent stem cells from mouse embryonic and adult fibroblast cultures by defined factors, Cell 126, 663-676 (2006).

6. A. S. Lee, C. Tang, M. S. Rao, I. L. Weissman, J. C. Wu, Tumorigenicity as a clinical hurdle for pluripotent stem cell therapies, Nat. Med. 19, 998-1004 (2013).

7. I. Maza, I. Caspi, A. Zviran, E. Chomsky, Y. Rais, S. Viukov, S. Geula, J. D. Buenrostro, L. Weinberger, V. Krupalnik, S. Hanna, M. Zerbib, J. R. Dutton, W. J. Greenleaf, R. Massarwa, N. Novershtern, J. H. Hanna, Transient acquisition of pluripotency during somatic cell transdifferentiation with iPSC 
reprogramming factors, Nat. Biotechnol. 33, 769-774 (2015).

8. M. Ieda, J.-D. Fu, P. Delgado-Olguin, V. Vedantham, Y. Hayashi, B. G. Bruneau, D. Srivastava, Direct reprogramming of fibroblasts into functional cardiomyocytes by defined factors, Cell 142, 375-386 (2010).

9. T. Vierbuchen, A. Ostermeier, Z. P. Pang, Y. Kokubu, T. C. Sudhof, M. Wernig, Direct conversion of fibroblasts to functional neurons by defined factors, Nature 463, 1035-1041 (2010).

10. S. Sekiya, A. Suzuki, Direct conversion of mouse fibroblasts to hepatocyte-like cells by defined factors, Nature 475, 390-393 (2011).

11. U. Ben-David, N. Benvenisty, The tumorigenicity of human embryonic and induced pluripotent stem cells, Nat. Rev. Cancer 11, 268-277 (2011).

12. I. Barbaric, V. Biga, P. J. Gokhale, M. Jones, D. Stavish, A. Glen, D. Coca, P. W. Andrews, Time-lapse analysis of human embryonic stem cells reveals multiple bottlenecks restricting colony formation and their relief upon culture adaptation, Stem Cell Reports 3, 142-155 (2014).

13. T. E. Werbowetski-Ogilvie, M. Bosse, M. Stewart, A. Schnerch, V. Ramos-Mejia, A. Rouleau, T. Wynder, M.-J. Smith, S. Dingwall, T. Carter, C. Williams, C. Harris, J. Dolling, C. Wynder, D. Boreham, M. Bhatia, Characterization of human embryonic stem cells with features of neoplastic progression, Nat. Biotechnol. 27, 91-97 (2009).

14. S. Bar, M. Schachter, T. Eldar-Geva, N. Benvenisty, Large-scale analysis of loss of imprinting in human pluripotent stem cells, Cell Rep. 19, 957-968 (2017).

15. S. Mekhoubad, C. Bock, A. S. de Boer, E. Kiskinis, A. Meissner, K. Eggan, Erosion of dosage compensation impacts human iPSC disease modeling, Cell Stem Cell 10, 595-609 (2012).

16. P. W. Andrews, U. Ben-David, N. Benvenisty, P. Coffey, K. Eggan, B. B. Knowles, A. Nagy, M. Pera, B. Reubinoff, P. J. Rugg-Gunn, G. N. Stacey, Assessing the safety of human pluripotent stem cells and their derivatives for clinical applications, Stem Cell Reports 9, 1-4 (2017). 
17. S. C. Dickinson, C. A. Sutton, K. Brady, A. Salerno, T. Katopodi, R. L. Williams, C. C. West, D.

Evseenko, L. Wu, S. Pang, R. Ferro De Godoy, A. E. Goodship, B. Peault, A. W. Blom, W. Kafienah, A. P. Hollander, The Wnt5a receptor, receptor tyrosine kinase-like orphan receptor 2, is a predictive cell surface marker of human mesenchymal stem cells with an enhanced capacity for chondrogenic differentiation, Stem Cells 35, 2280-2291 (2017).

18. A. Kirkeby, S. Nolbrant, K. Tiklova, A. Heuer, N. Kee, T. Cardoso, D. Rylander Ottosson, M. J. Lelos, P. Rifes, S. B. Dunnett, S. Grealish, T. Perlmann, M. Parmar, Predictive markers guide differentiation to improve graft outcome in clinical translation of hESC-based therapy for Parkinson's disease, Cell Stem Cell 20, 135-148 (2017).

19. F. M. Watt, B. L. M. Hogan, Out of Eden: stem cells and their niches, Science 287, 1427-1430 (2000).

20. J. P. K. Armstrong, A. W. Perriman, Strategies for cell membrane functionalization, Exp. Biol. Med. 241, 1098-1106 (2016).

21. M. D. Mager, V. LaPointe, M. M. Stevens, Exploring and exploiting chemistry at the cell surface, Nat. Chem. 3, 582-589 (2011).

22. M. M. Stevens, J. H. George, Exploring and engineering the cell surface interface, Science 310, 11351138 (2005).

23. T. L. Downing, J. Soto, C. Morez, T. Houssin, A. Fritz, F. Yuan, J. Chu, S. Patel, D. V Schaffer, S. Li, Biophysical regulation of epigenetic state and cell reprogramming, Nat. Mater. 12, 1154-1162 (2013).

24. S. W. Crowder, V. Leonardo, T. Whittaker, P. Papathanasiou, M. M. Stevens, Material cues as potent regulators of epigenetics and stem cell function, Cell Stem Cell 18, 39-52 (2016).

25. N. D. Leipzig, M. S. Shoichet, The effect of substrate stiffness on adult neural stem cell behavior, Biomaterials 30, 6867-6878 (2009).

26. B. M. Willie, A. Petersen, K. Schmidt-Bleek, A. Cipitria, M. Mehta, P. Strube, J. Lienau, B. Wildemann, 
P. Fratzl, G. Duda, Designing biomimetic scaffolds for bone regeneration: why aim for a copy of mature tissue properties if nature uses a different approach?, Soft Matter 6, 4976-4987 (2010).

27. C. Li, L. Ouyang, I. J. Pence, A. C. Moore, Y. Lin, C. W. Winter, J. P. K. Armstrong, M. M. Stevens, Buoyancy-driven gradients for biomaterial fabrication and tissue engineering, Adv. Mater. 31, 1900291 (2019).

28. J. L. Young, A. J. Engler, Hydrogels with time-dependent material properties enhance cardiomyocyte differentiation in vitro, Biomaterials 32, 1002-1009 (2011).

29. J. P. K. Armstrong, M. Burke, B. M. Carter, S. A. Davis, A. W. Perriman, 3D bioprinting using a templated porous bioink, Adv. Healthc. Mater. 5, 1724-1730 (2016).

30. W. Bian, B. Liau, N. Badie, N. Bursac, Mesoscopic hydrogel molding to control the 3D geometry of bioartificial muscle tissues, Nat. Protoc. 4, 1522-1534 (2009).

31. A. J. Thornton, E. Alsberg, M. Albertelli, D. J. Mooney, Shape-defining scaffolds for minimally invasive tissue engineering, Transplantation 77, 1798-1803 (2004).

32. G. D. Nicodemus, S. J. Bryant, Cell encapsulation in biodegradable hydrogels for tissue engineering applications, Tissue Eng. Part B 14, 149-165 (2008).

33. K. W. Ng, L. E. Kugler, S. B. Doty, G. A. Ateshian, C. T. Hung, Scaffold degradation elevates the collagen content and dynamic compressive modulus in engineered articular cartilage, Osteoarthr. Cartil. 17, 220-227 (2009).

34. C. A. Janeway, R. Medzhitov, Innate immune recognition, Annu. Rev. Immunol. 20, 197-216 (2002).

35. R. Medzhitov, C. A. Janeway, Decoding the patterns of self and nonself by the innate immune system, Science 296, 298-301 (2002).

36. T. Boehm, Design principles of adaptive immune systems, Nat. Rev. Immunol. 11, 307-317 (2011).

37. J. L. Zakrzewski, M. R. M. Van den Brink, J. A. Hubbell, Overcoming immunological barriers in 
regenerative medicine, Nat. Biotechnol. 32, 786-794 (2014).

38. Y. Mizukami, T. Abe, H. Shibata, Y. Makimura, S.-H. Fujishiro, K. Yanase, S. Hishikawa, E. Kobayashi, Y. Hanazono, MHC-matched induced pluripotent stem cells can attenuate cellular and humoral immune responses but are still susceptible to innate immunity in pigs, PLoS One 9, e98319 (2014).

39. Z. S. Scheiner, S. Talib, E. G. Feigal, The potential for immunogenicity of autologous induced pluripotent stem cell-derived therapies, J. Biol. Chem. 289, 4571-4577 (2014).

40. K. Sadtler, A. Singh, M. T. Wolf, X. Wang, D. M. Pardoll, J. H. Elisseeff, Design, clinical translation and immunological response of biomaterials in regenerative medicine, Nat. Rev. Mater. 1, 16040 (2016).

41. J. M. Anderson, A. Rodriguez, D. T. Chang, Foreign body reaction to biomaterials, Semin. Immunol. 20, 86-100 (2008).

42. M. Krampera, L. Cosmi, R. Angeli, A. Pasini, F. Liotta, A. Andreini, V. Santarlasci, B. Mazzinghi, G. Pizzolo, F. Vinante, P. Romagnani, E. Maggi, S. Romagnani, F. Annunziato, Role for interferon-gamma in the immunomodulatory activity of human bone marrow mesenchymal stem cell, Stem Cells $\mathbf{2 4}$, 386-398 (2006).

43. O. Veiseh, J. C. Doloff, M. Ma, A. J. Vegas, H. H. Tam, A. R. Bader, J. Li, E. Langan, J. Wyckoff, W. S. Loo, S. Jhunjhunwala, A. Chiu, S. Siebert, K. Tang, J. Hollister-Lock, S. Aresta-Dasilva, M. Bochenek, J. Mendoza-Elias, Y. Wang, M. Qi, D. M. Lavin, M. Chen, N. Dholakia, R. Thakrar, I. Lacík, G. C. Weir, J. Oberholzer, D. L. Greiner, R. Langer, D. G. Anderson, Size- and shape-dependent foreign body immune response to materials implanted in rodents and non-human primates, Nat. Mater. 14, 643-652 (2015).

44. D. D. Lasic, D. Needham, The "stealth" liposome: a prototypical biomaterial, Chem. Rev. 95, 2601-2628 (1995).

45. N. Moriarty, A. Pandit, E. Dowd, Encapsulation of primary dopaminergic neurons in a GDNF- loaded collagen hydrogel increases their survival, re-innervation and function after intra-striatal transplantation, Sci. Rep. 7, 16033 (2017). 
46. X. Wang, J. Qin, R. C. Zhao, M. Zenke, Reduced immunogenicity of induced pluripotent stem cells derived from Sertoli cells, PLoS One 9, e106110 (2014).

47. T. Deuse, X. Hu, A. Gravina, D. Wang, G. Tediashvili, C. De, W. O. Thayer, A. Wahl, J. V. Garcia, H. Reichenspurner, M. M. Davis, L. L. Lanier, S. Schrepfer, Hypoimmunogenic derivatives of induced pluripotent stem cells evade immune rejection in fully immunocompetent allogeneic recipients, Nat. Biotechnol. 37, 252-258 (2019).

48. S. A. Eming, T. A. Wynn, P. Martin, Inflammation and metabolism in tissue repair and regeneration, Science 356, 1026-1030 (2017).

49. K. Sadtler, K. Estrellas, B. W. Allen, M. T. Wolf, H. Fan, A. J. Tam, C. H. Patel, B. S. Luber, H. Wang, K. R. Wagner, J. D. Powell, F. Housseau, D. M. Pardoll, J. H. Elisseeff, Developing a pro-regenerative biomaterial scaffold microenvironment requires T helper 2 cells, Biomaterials 352, 366-371 (2016).

50. T. M. Raimondo, D. J. Mooney, Functional muscle recovery with nanoparticle-directed M2 macrophage polarization in mice, Proc. Natl. Acad. Sci. U. S. A. 115, 10648-10653 (2018).

51. V. Karantalis, D. L. DiFede, G. Gerstenblith, S. Pham, J. Symes, J. P. Zambrano, J. Fishman, P. Pattany, I. McNiece, J. Conte, S. Schulman, K. Wu, A. Shah, E. Breton, J. Davis-Sproul, R. Schwarz, G. Feigenbaum, M. Mushtaq, V. Y. Suncion, A. C. Lardo, I. Borrello, A. Mendizabal, T. Z. Karas, J. Byrnes, M. Lowery, A. W. Heldman, J. M. Hare, Autologous mesenchymal stem cells produce concordant improvements in regional function, tissue perfusion, and fibrotic burden when administered to patients undergoing coronary artery bypass grafting, Circ. Res. 114, 1302-1310 (2014).

52. J. H. Ardenkjær-Larsen, B. Fridlund, A. Gram, G. Hansson, L. Hansson, M. H. Lerche, R. Servin, M. Thaning, K. Golman, Increase in signal-to-noise ratio of $>10,000$ times in liquid-state NMR, Proc. Natl. Acad. Sci. USA 100, 10158-10163 (2003).

53. C. H. Cunningham, J. Y. C. Lau, A. P. Chen, B. J. Geraghty, W. J. Perks, I. Roifman, G. A. Wright, K. A. Connelly, Hyperpolarized 13C metabolic MRI of the human heart, Circ. Res. 119, 1177-1182 (2016). 
54. W. Drexler, U. Morgner, R. K. Ghanta, F. X. Kartner, J. S. Schuman, J. G. Fujimoto, Ultrahighresolution ophthalmic optical coherence tomography, Nat. Med. 7, 502-507 (2001).

55. P. Hossain, A. Sachdev, R. A. Malik, Early detection of diabetic peripheral neuropathy with corneal confocal microscopy, Lancet 366, 1340-1343 (2005).

56. W. Choi, E.-Y. Park, S. Jeon, C. Kim, Clinical photoacoustic imaging platforms, Biomed. Eng. Lett. 8, 139-155 (2018).

57. R. Bi, U. S. Dinish, C. C. Goh, T. Imai, M. Moothanchery, X. Li, J. Y. Kim, S. Jeon, Y. Pu, C. Kim, L. G. Ng, L. V. Wang, M. Olivo, In vivo label-free functional photoacoustic monitoring of ischemic reperfusion, J. Biophotonics 12, e201800454 (2019).

58. P. Zhang, L. Li, L. Lin, P. Hu, J. Shi, Y. He, L. Zhu, Y. Zhou, L. V. Wang, High-resolution deep functional imaging of the whole mouse brain by photoacoustic computed tomography in vivo, $J$. Biophotonics 11, e201700024 (2018).

59. C. Rabut, M. Correia, V. Finel, S. Pezet, M. Pernot, T. Deffieux, M. Tanter, 4D functional ultrasound imaging of whole-brain activity in rodents, Nat. Methods 16, 994-997 (2019).

60. K. Yano, T. Namikawa, T. Uemura, M. Hoshino, S. Wakitani, K. Takaoka, H. Nakamura, Regenerative repair of bone defects with osteoinductive hydroxyapatite fabricated to match the defect and implanted with combined use of computer-aided design, computer-aided manufacturing, and computer-assisted surgery systems: a feasibility study in a c, J. Orthop. Sci. 17, 484-489 (2012).

61. F. A. Barber, W. D. Dockery, A computed tomography scan assessment of synthetic multiphase polymer scaffolds used for osteochondral defect repair, Arthrosc. J. Arthrosc. Relat. Surg. 27, 60-64 (2011).

62. M. F. Kircher, S. S. Gambhir, J. Grimm, Noninvasive cell-tracking methods, Nat. Rev. Clin. Oncol. 8, 677-688 (2011).

63. D. S. Wilbur, Radiohalogenation of proteins: an overview of radionuclides, labeling methods and 
reagents for conjugate labeling, Bioconjug. Chem. 3, 433-470 (1992).

64. D. Blocklet, M. Toungouz, G. Berkenboom, M. Lambermont, P. Unger, N. Preumont, E. Stoupel, D. Egrise, J.-P. Degaute, M. Goldman, S. Goldman, Myocardial homing of nonmobilized peripheral-blood CD34+ cells after intracoronary injection, Stem Cells 24, 333-336 (2006).

65. T. Eich, O. Eriksson, T. Lundgren, Visualization of early engraftment in clinical islet transplantation by positron-emission tomography, N. Engl. J. Med. 356, 2754-2755 (2007).

66. C. R. Freed, P. E. Greene, R. E. Breeze, W.-Y. Tsai, W. DuMouchel, R. Kao, S. Dillon, H. Winfield, S. Culver, J. Q. Trojanowski, D. Eidelberg, S. Fahn, Transplantation of embryonic dopamine neurons for severe Parkinson's disease, N. Engl. J. Med. 344, 710-719 (2001).

67. P. Piccini, D. J. Brooks, A. Björklund, R. N. Gunn, P. M. Grasby, O. Rimoldi, P. Brundin, P. Hagell, S. Rehncrona, H. Widner, O. Lindvall, Dopamine release from nigral transplants visualized in vivo in a Parkinson's patient, Nat. Neurosci. 2, 1137-1140 (1999).

68. S. S. Yaghoubi, M. C. Jensen, N. Satyamurthy, S. Budhiraja, D. Paik, J. Czernin, S. S. Gambhir, Noninvasive detection of therapeutic cytolytic T cells with 18F-FHBG PET in a patient with glioma, Nat. Clin. Pract. Oncol. 6, 53-58 (2009).

69. R. D. Badawi, H. Shi, P. Hu, S. Chen, T. Xu, P. M. Price, Y. Ding, B. A. Spencer, L. Nardo, W. Liu, J. Bao, T. Jones, H. Li, S. R. Cherry, First human imaging studies with the EXPLORER total-body PET scanner, J. Nucl. Med. 60, 299-303 (2019).

70. L. da Cruz, K. Fynes, O. Georgiadis, J. Kerby, Y. H. Luo, A. Ahmado, A. Vernon, J. T. Daniels, B. Nommiste, S. M. Hasan, S. B. Gooljar, A.-J. F. Carr, A. Vugler, C. M. Ramsden, M. Bictash, M. Fenster, J. Steer, T. Harbinson, A. Wilbrey, A. Tufail, G. Feng, M. Whitlock, A. G. Robson, G. E. Holder, M. S. Sagoo, P. T. Loudon, P. Whiting, P. J. Coffey, Phase 1 clinical study of an embryonic stem cell-derived retinal pigment epithelium patch in age-related macular degeneration, Nat. Biotechnol. 36, 328-337 (2018).

71. E. Curtis, J. R. Martin, B. Gabel, N. Sidhu, T. K. Rzesiewicz, R. Mandeville, S. Van Gorp, M. Leerink, 
T. Tadokoro, S. Marsala, C. Jamieson, M. Marsala, J. D. Ciacci, A first-in-human, phase I study of neural stem cell transplantation for chronic spinal cord injury, Cell Stem Cell 22, 941-950 (2018).

72. A. Sanyal, E. D. Charles, B. A. Neuschwander-Tetri, R. Loomba, S. A. Harrison, M. F. Abdelmalek, E. J. Lawitz, D. Halegoua-DeMarzio, S. Kundu, S. Noviello, Y. Luo, C. Rose, Pegbelfermin (BMS-986036), a PEGylated fibroblast growth factor 21 analogue, in patients with non-alcoholic steatohepatitis: a randomised, double-blind, placebo-controlled, phase 2a trial, Lancet 392, 2705-2717 (2018).

73. M. Mandai, A. Watanabe, Y. Kurimoto, Y. Hirami, C. Morinaga, T. Daimon, M. Fujihara, H. Akimaru, N. Sakai, Y. Shibata, M. Terada, Y. Nomiya, S. Tanishima, M. Nakamura, H. Kamao, S. Sugita, A. Onishi, T. Ito, K. Fujita, S. Kawamata, M. J. Go, C. Shinohara, K. Hata, M. Sawada, M. Yamamoto, S. Ohta, Y. Ohara, K. Yoshida, J. Kuwahara, Y. Kitano, N. Amano, M. Umekage, F. Kitaoka, A. Tanaka, C. Okada, N. Takasu, S. Ogawa, S. Yamanaka, M. Takahashi, Autologous induced stem-cell-derived retinal cells for macular degeneration, N. Engl. J. Med. 376, 1038-1046 (2017).

74. D. Cyranoski, Woman is first to receive cornea made from 'reprogrammed' stem cells, Nat. News (2019).

75. D. Cyranoski, 'Reprogrammed' stem cells to treat spinal-cord injuries for the first time, Nat. News (2019).

76. D. Cyranoski, 'Reprogrammed' stem cells implanted into patient with Parkinson's disease, Nat. News (2018).

77. E. T. Pashuck, M. M. Stevens, Designing regenerative biomaterial therapies for the clinic, Sci. Transl. Med. 4, 160sr4 (2012).

78. T. Bubela, C. McCabe, Value-engineered translation for regenerative medicine: meeting the needs of health systems, Stem Cells Dev. 22, 89-94 (2013).

79. T. McAllister, N. Dusserre, M. Maruszewski, N. L’Heureux, Cell-based therapeutics from an economic perspective: primed for a commercial success or a research sinkhole?, Regen. Med. 3, 925-937 (2008). 
80. R. Sanzenbacher, A. Dwenger, M. Schuessler-Lenz, K. Cichutek, E. Flory, European regulation tackles tissue engineering, Nat. Biotechnol. 25, 1089-1091 (2007).

81. S. Nagai, Flexible and expedited regulatory review processes for innovative medicines and regenerative medical products in the US, the EU, and Japan, Int. J. Mol. Sci. 20, 3801 (2019).

82. M. K. Wilson, K. Karakasis, A. M. Oza, Outcomes and endpoints in trials of cancer treatment: the past, present, and future, Lancet Oncol. 16, e32-e42 (2015).

83. J. Cibelli, M. E. Emborg, D. J. Prockop, M. Roberts, G. Schatten, M. Rao, J. Harding, O.

Mirochnitchenko, Strategies for improving animal models for regenerative medicine, Stem Cell 12, 271-274 (2013).

84. R. Archer, D. J. Williams, Why tissue engineering needs process engineering, Nat. Biotechnol. 23, 13531355 (2005).

85. S. Sullivan, G. N. Stacey, C. Akazawa, N. Aoyama, R. Baptista, P. Bedford, A. Bennaceur Griscelli, A. Chandra, N. Elwood, M. Girard, S. Kawamata, T. Hanatani, T. Latsis, S. Lin, T. E. Ludwig, T. Malygina, A. Mack, J. C. Mountford, S. Noggle, L. V. Pereira, J. Price, M. Sheldon, A. Srivastava, H. Stachelscheid, S. R. Velayudhan, N. J. Ward, M. L. Turner, J. Barry, J. Song, Quality control guidelines for clinical-grade human induced pluripotent stem cell lines, Regen. Med. 13, 859-866 (2018).

86. P. Salmikangas, M. Menezes-Ferreira, I. Reischl, A. Tsiftsoglou, J. Kyselovic, J. J. Borg, S. Ruiz, E. Flory, J.-H. Trouvin, P. Celis, J. Ancans, M. Timon, G. Pante, D. Sladowski, M. Lipnik-Stangelj, C. K. Schneider, Manufacturing, characterization and control of cell-based medicinal products: challenging paradigms toward commercial use, Regen. Med. 10, 65-78 (2015).

87. I. Martin, D. Wendt, M. Heberer, The role of bioreactors in tissue engineering, Trends Biotechnol. 22, 80-86 (2004).

88. D. J. Williams, R. Archer, P. Archibald, I. Bantounas, R. Baptista, R. Barker, J. Barry, F. Bietrix, N. Blair, J. Braybrook, J. Campbell, M. Canham, A. Chandra, G. Foldes, R. Gilmanshin, M. Girard, E. Gorjup, 
Z. Hewitt, P. Hourd, J. Hyllner, H. Jesson, J. Kee, J. Kerby, N. Kotsopoulou, S. Kowalski, C. Leidel, D. Marshall, L. Masi, M. McCall, C. Mccann, N. Medcalf, H. Moore, H. Ozawa, D. Pan, M. Parmar, A. L. Plant, Y. Reinwald, S. Sebastian, G. Stacey, R. J. Thomas, D. Thomas, J. Thurman-Newell, M. Turner, L. Vitillo, I. Wall, A. Wilson, J. Wolfrum, Y. Yang, H. Zimmerman, Comparability: manufacturing, characterization and controls, report of a UK Regenerative Medicine Platform pluripotent stem cell platform workshop, Trinity Hall, Cambridge, 14-15 September 2015, Regen. Med. 115, 483-492 (2016).

89. T. R. J. Heathman, A. W. Nienow, M. J. McCall, K. Coopman, B. Kara, C. J. Hewitt, The translation of cell-based therapies: clinical landscape and manufacturing challenges, Regen. Med. 10, 49-64 (2015).

90. D. J. Williams, R. J. Thomas, P. C. Hourd, A. Chandra, E. Ratcliffe, Y. Liu, E. A. Rayment, J. R. Archer, Precision manufacturing for clinical-quality, Philos. Trans. R. Soc. A 370, 3924-3949 (2012).

91. I. Martin, P. J. Simmons, D. F. Williams, Manufacturing challenges in regenerative medicine, Sci. Transl. Med. 6, 232fs16 (2014).

92. C. A. Herberts, M. S. G. Kwa, H. P. H. Hermsen, Risk factors in the development of stem cell therapy, J. Transl. Med. 9, 29 (2011).

93. J. P. K. Armstrong, M. M. Stevens, Emerging technologies for tissue engineering: from gene editing to personalized medicine, Tissue Eng. Part A 25, 688-692 (2019).

94. P.-H. Sung, H.-S. Lin, W.-C. Lin, C.-C. Chang, S.-N. Pei, M.-C. Ma, K.-H. Chen, J. Y. Chiang, H.-W. Chang, F.-Y. Lee, M. S. Lee, H.-K. Yip, Intra-carotid arterial transfusion of autologous circulatory derived CD34+ cells for old ischemic stroke patients - a phase I clinical trial to evaluate safety and tolerability, Am. J. Transl. Res. 10, 2975-2989 (2018).

95. F. Moroni, B. J. Dwyer, C. Graham, C. Pass, L. Bailey, L. Ritchie, D. Mitchell, A. Glover, A. Laurie, S. Doig, E. Hargreaves, A. R. Fraser, M. L. Turner, J. D. M. Campbell, N. W. A. McGowan, J. Barry, J. K. Moore, P. C. Hayes, D. J. Leeming, M. J. Nielsen, K. Musa, J. A. Fallowfield, S. J. Forbes, Safety profile of autologous macrophage therapy for liver cirrhosis, Nat. Med. 25, 1560-1565 (2019). 
96. S. Shadmanfar, N. Labibzadeh, M. Emadedin, N. Jaroughi, V. Azimian, S. Mardpour, F. A. Kakroodi, T. Bolurieh, S. E. Hosseini, M. Chehrazi, M. Niknejadi, H. Baharvand, F. Gharibdoost, N. Aghdami, Intraarticular knee implantation of autologous bone marrow-derived mesenchymal stromal cells in rheumatoid arthritis patients with knee involvement: results of a randomized, triple-blind, placebo-controlled phase 1/2 clinical trial, Cytotherapy 20, 499-506 (2018).

97. L. Lu, C. Dai, Z. Zhang, H. Du, S. Li, P. Ye, Q. Fu, L. Zhang, X. Wu, Y. Dong, Y. Song, D. Zhao, Y. Pang, C. Bao, Treatment of knee osteoarthritis with intra-articular injection of autologous adipose-derived mesenchymal progenitor cells: a prospective, randomized, double-blind, active-controlled, phase IIb clinical trial, Stem Cell Res. Ther. 10, 143 (2019).

98. D. Cadavid, M. Mellion, R. Hupperts, K. R. Edwards, P. A. Calabresi, J. Drulović, G. Giovannoni, H.-P. Hartung, D. L. Arnold, E. Fisher, R. Rudick, S. Mi, Y. Chai, J. Li, Y. Zhang, W. Cheng, L. Xu, B. Zhu, S. M. Green, I. Chang, A. Deykin, S. I. Sheikh, Safety and efficacy of opicinumab in patients with relapsing multiple sclerosis (SYNERGY): a randomised, placebo-controlled, phase 2 trial, Lancet Neurol. 18, 845-856 (2019).

99. P. N. Newsome, R. Fox, A. L. King, D. Barton, N.-N. Than, J. Moore, C. Corbett, S. Townsend, J. Thomas, K. Guo, D. Hull, H. A. Beard, J. Thompson, A. Atkinson, C. Bienek, N. McGowan, N. Guha, J. Campbell, D. Hollyman, D. Stocken, C. Yap, S. J. Forbes, Granulocyte colony-stimulating factor and autologous CD133-positive stem-cell therapy in liver cirrhosis (REALISTIC): an open-label, randomised, controlled phase 2 trial, Lancet Gastroenterol. Hepatol. 3, 25-36 (2018). 